\title{
Methods for studying synaptosomal copper release
}

\author{
Alexander Hopt ${ }^{\mathrm{a}, *, 1}$, Stefan Korte ${ }^{\mathrm{a}, 1}$, Herbert Fink ${ }^{\mathrm{b}}$, Ulrich Panne ${ }^{\mathrm{b}}$, \\ Reinhard Niessner ${ }^{b}$, Reinhard Jahn ${ }^{c}$, Hans Kretzschmar ${ }^{a}$, Jochen Herms ${ }^{\mathrm{a}, *}$ \\ a Institut für Neuropathologie, Ludwig-Maximilians-Universität München, Marchioninistr. 17, 81377 München, Germany \\ b Institut für Wasserchemie, Technische Universität München, Marchioninistr. 17, München, Germany \\ c Abteilung Neurobiologie, Max-Planck Institut für biophysikalische Chemie, Am Faßberg, Göttingen, Germany
}

Received 31 October 2002; received in revised form 7 June 2003; accepted 11 June 2003

\begin{abstract}
$\mathrm{Cu}$ is thought to play an important role in the pathogenesis of several neurodegenerative diseases, such as Wilson's, Alzheimer's, and probably in prion protein diseases like Creutzfeld-Jakob's disease. Until now, no method existed to determine the concentration of this cation in vivo. Here, we present two possible approaches combined with a critical comparison of the results. The successful use of fluorescent ligands for the determination of $\mathrm{Ca}^{2+}$-concentrations in recent years encouraged us to seek a fluorophore which specifically reacts to $\mathrm{Cu}^{2+}$ and to characterize it for our purposes. We found that the emission of TSPP (tetrakis(4-sulfophenyl)porphine) at an emission wavelength of $645 \mathrm{~nm}$ is in vitro highly specific to $\mathrm{Cu}^{2+}$ (apparent dissociation constant $K_{\mathrm{d}}=0.43 \pm 0.07 \mu \mathrm{M}$ at $\left.\mathrm{pH} 7.4\right)$. It does not react with the most common divalent cations in the brain, $\mathrm{Ca}^{2+}$ and $\mathrm{Mg}^{2+}$, unlike most of the other dyes examined. In addition, $\mathrm{Zn}^{2+}$ quenches TSPP fluorescence at a different emission wavelength (605 nm) with a $K_{\mathrm{d}}$ of $50 \pm 2.5 \mu \mathrm{M}$ (pH 7.0). With these findings, we applied the measurement of $\mathrm{Cu}$ with TSPP to a biological system, showing for the first time in vivo that there is release of copper by synaptosomes upon depolarisation. Our findings were validated with a completely independent analytical approach based on ICP-MS (inductively-coupled-plasma mass-spectrometry).
\end{abstract}

(C) 2003 Elsevier B.V. All rights reserved.

Keywords: Synaptosomes; Synapse; Copper; Copper concentration; Fluorescence; ICP-MS

\section{Introduction}

The divalent copper ion is an essential trace metal, which plays a fundamental role in the biochemistry of the human nervous system. Inherited disorders of the copper metabolism such as Menkes and Wilsons diseases have dramatic neurodegenerative phenotypes and underscore this essential role of copper in the brain (DiDonato and Sarkar, 1997). Also neuronal injury in neurodegenerative diseases such as Alzheimer disease, Parkinson disease, amyotrophic lateral sclerosis, and Creutzfeldt-Jakob disease (CJD) are thought to be at

* Corresponding authors. Present address: University Hospital Charit, Neurology, Schumannstrasse 2021, 10117 Berlin, Germany. Tel.: +49-89-2180-78010; fax: +49-89-2180-78037 (J.H.); Tel.: +4930-450-560015; fax: +49-30-450-560952 (A.H.).

E-mail addresses: alexander.hopt@charite.de (A. Hopt), jochen.herms@inp.med.uni-muenchen.de (J. Herms).

1 These authors contributed equally to this work. least in part due to alterations in copper metabolism (Waggoner et al., 1999). Copper is known for the catalytic activity of enzymes which probably play a role in these diseases, including tyrosinase for melanin synthesis, cytochrome $c$ oxidase for the electron transport in the mitochondrial respiratory chain, $\mathrm{Cu} / \mathrm{Zn}$ superoxide dismutase for antioxidant defense, and dopamine $\beta$-hydroxylase for catecholamine biosynthesis. In Creutzfeldt-Jakob disease the pathogenetic link is due to the copper-binding ability of the cellular prion protein $\left(\operatorname{PrP}^{\mathrm{c}}\right)$ (Brown et al., 1997), a protein which accumulates in its conformational altered isoform $\left(\mathrm{PrP}^{\mathrm{SC}}\right)$ in diseased brains. Considering the importance of copper, it is astonishing that there is yet no method to determine $\mathrm{Cu}$-concentrations in vivo.

Evaluating a group of fluorescent ligands in vitro, we found tetrakis-(4-sulfophenyl)-porphine (TSPP, see inlay of Fig. 2A) to be a possible $\mathrm{Cu}^{2+}$-specific indicator. Other fluorophores, such as tetrakis-(4-carboxyphenyl)porphine (TCPP), Phen Green, and most of the common 
calcium indicators (Fura Red, Fluo 3, Ca Green 1, Ca Crimson) either didn't react with copper at all or were also influenced by other metal ions tested $\left(\mathrm{Na}^{+}, \mathrm{K}^{+}\right.$, $\mathrm{Cu}^{2+}, \mathrm{Zn}^{2+}, \mathrm{Mg}^{2+}, \mathrm{Ca}^{2+}, \mathrm{Co}^{2+}, \mathrm{Cd}^{2+}, \mathrm{Mn}^{2+}$, and $\left.\mathrm{Fe}^{3+}\right)$. The corresponding apparent dissociation constants $\left(K_{\mathrm{d}}\right)$ were determined (Table 1$)$ as described below.

After acquiring the results in vitro, we applied the dye to a biological system by studying depolarization of synaptosomes. We finally made a crosscheck of our results by analyzing the total copper concentration in the surplus of synaptosomal solutions with another independent analytical method, inductively-coupledplasma mass-spectrometry (ICP-MS). Regarding the findings we are able to present here a method to study $\mathrm{Cu}^{2+}$-concentrations in vivo using TSPP as a $\mathrm{Cu}^{2+}$ specific fluorophore. With this method, we were able to show for the first time qualitatively and quantitatively a depolarization-induced release of copper by synaptosomes.

\section{Methods}

All solutions were prepared with ultrapure water (Millipore, Eschborn, FRG) with a minimal resistance of $18 \mathrm{M} \Omega$ all reagents were analytical grade. The water was additionally filtered with Chelex-100 (Sigma-Aldrich, Deisenhofen, GER) before use. All dyes were purchased from Molecular Probes (Leiden, NL). After each measurement the cuvette was washed with Hellmanex II (Hellma, Essex), with a solution of $10 \mathrm{mM}$ EGTA (Sigma-Aldrich, Deisenhofen, GER), then three times with Chelex water and finally with ethanol. It was dried with $\mathrm{N}_{2}$.

\subsection{Cell permeability of TSPP}

We used a LSM 410 (Zeiss, Jena, GER) confocal microscope to image the autofluorescence of bovine chromaffin cells, which was maximal if imaged with a bandpass filter of 510-525 nm (Zeiss, Jena, GER). The preparation of bovine chromaffin cells was similar to the method of Smith (1999). After adding TSPP to the physiological buffer to a final concentration of $10 \mu \mathrm{M}$, we took images of the autofluorescence and the fluorescence of TSPP (filter $700 \pm 40 \mathrm{~nm}$, Omega Optical, Brattleboro, USA) every $10 \mathrm{~min}$, exciting the dye with a $488 \mathrm{~nm}$ Ar-ion laser. TSPP fluorescence was acquired with a red-sensitive photomultiplier (R3896, Hamamatsu, Munich, GER).

\subsection{Spectrum of the dyes}

All fluorescence spectra were recorded with a LS50 spectrofluorometer (Perkin-Elmer, Norwalk, USA) at $(37 \pm 0.5)^{\circ} \mathrm{C}$, with exception of one experiment determining the influence of the temperature on the dissociation constant of TSPP with $\mathrm{Cu}^{2+}$. The temperature was determined before and after every experimental proce-

Table 1

Characteristic excitation and emission wavelengths and dissociation constants of the fluorescent ligands under study

\begin{tabular}{|c|c|c|c|c|c|c|c|}
\hline Ion & $\begin{array}{l}\text { Ca-Green-1 Ex. } 488 \\
\text { nm }\end{array}$ & $\begin{array}{l}\text { Ca-Crimson Ex. } 570 \\
\mathrm{~nm}\end{array}$ & $\begin{array}{l}\text { Fura Red Ex. } 488 \\
\text { nm }\end{array}$ & $\begin{array}{l}\text { Fluo-3 Ex. } 488 \\
\text { nm }\end{array}$ & $\begin{array}{l}\text { TSPP Ex. } 414 \\
\mathrm{~nm}\end{array}$ & $\begin{array}{l}\text { TCPP Ex. } 414 \\
\text { nm }\end{array}$ & $\begin{array}{l}\text { Phen Green Ex. } 488 \\
\text { nm }\end{array}$ \\
\hline $\mathrm{Ca}^{2+}$ & $\begin{array}{l}529 \mathrm{~nm} \uparrow \\
0.20 \mu \mathrm{M}\end{array}$ & $\begin{array}{l}607 \mathrm{~nm} \uparrow \\
0.19 \mu \mathrm{M}\end{array}$ & $\begin{array}{l}620 \mathrm{~nm} \downarrow \\
0.14 \mu \mathrm{M}\end{array}$ & $\begin{array}{l}525 \mathrm{~nm} \uparrow \\
0.40 \mu \mathrm{M}\end{array}$ & - & $\begin{array}{l}645 \mathrm{~nm} \uparrow \\
0.50 \mu \mathrm{M}\end{array}$ & - \\
\hline $\mathrm{Mg}^{2+}$ & $\begin{array}{l}529 \mathrm{~nm} \downarrow \\
0.25 \mu \mathrm{M}\end{array}$ & - & - & - & - & - & - \\
\hline $\mathrm{Zn}^{2+}$ & - & $\begin{array}{l}607 \mathrm{~nm} \uparrow \\
1.00 \mu \mathrm{M}\end{array}$ & - & $\begin{array}{l}525 \mathrm{~nm} \uparrow \\
0.10 \mu \mathrm{M}\end{array}$ & $\begin{array}{l}605 \mathrm{~nm} \uparrow \\
50.00 \mu \mathrm{M}\end{array}$ & $\begin{array}{l}645 \mathrm{~nm} \downarrow \\
9.00 \mu \mathrm{M} \\
605 \mathrm{~nm} \uparrow \\
9.00 \mu \mathrm{M}\end{array}$ & $\begin{array}{l}525 \mathrm{~nm} \downarrow \\
0.20 \mu \mathrm{M}\end{array}$ \\
\hline $\mathrm{Cu}^{2+}$ & $\begin{array}{r}529 \mathrm{~nm} \downarrow \\
0.05 \mu \mathrm{M}\end{array}$ & $\begin{array}{l}607 \mathrm{~nm} \downarrow \\
0.25 \mu \mathrm{M}\end{array}$ & $\begin{array}{l}620 \mathrm{~nm} \downarrow \\
2.50 \mu \mathrm{M}\end{array}$ & $\begin{array}{l}525 \mathrm{~nm} \downarrow \\
0.10 \pm 0.05 \mu \mathrm{M}\end{array}$ & $\begin{array}{l}645 \mathrm{~nm} \downarrow \\
0.43 \pm 0.07 \mu \mathrm{M}\end{array}$ & $\begin{array}{l}645 \mathrm{~nm} \downarrow \\
0.30 \mu \mathrm{M}\end{array}$ & $\begin{array}{l}525 \mathrm{~nm} \downarrow \\
0.30 \mu \mathrm{M}\end{array}$ \\
\hline $\mathrm{Co}^{2+}$ & $\begin{array}{l}529 \mathrm{~nm} \downarrow \\
0.20 \mu \mathrm{M}\end{array}$ & $\begin{array}{r}607 \mathrm{~nm} \downarrow \\
\quad 0.70 \mu \mathrm{M}\end{array}$ & $\begin{array}{r}620 \mathrm{~nm} \downarrow \\
1.20 \mu \mathrm{M}\end{array}$ & $\begin{array}{l}525 \mathrm{~nm} \uparrow \\
5.70 \mu \mathrm{M}\end{array}$ & $\begin{array}{l}645 \mathrm{~nm}(\downarrow) \\
0.20 \pm 0.1 \mu \mathrm{M}\end{array}$ & $\begin{array}{l}645 \mathrm{~nm} \downarrow \\
0.05 \pm 0.01 \mu \mathrm{M}\end{array}$ & $\begin{array}{l}525 \mathrm{~nm} \downarrow \\
0.25 \mu \mathrm{M}\end{array}$ \\
\hline $\mathrm{Cd}^{2+}$ & - & - & $\begin{array}{c}620 \mathrm{~nm} \downarrow \\
2.50 \mu \mathrm{M}\end{array}$ & - & - & $\begin{array}{c}645 \mathrm{~nm} \downarrow \\
0.02 \pm 0.01 \mu \mathrm{M} \\
605 \mathrm{~nm} \uparrow \\
0.01 \pm 0.01 \mu \mathrm{M}\end{array}$ & $\begin{array}{c}525 \mathrm{~nm} \downarrow \\
0.02 \pm 0.01 \mu \mathrm{M}\end{array}$ \\
\hline $\mathrm{Fe}^{3+}$ & $\begin{array}{l}529 \mathrm{~nm} \downarrow \\
0.20 \mu \mathrm{M}\end{array}$ & $\begin{array}{l}607 \mathrm{~nm} \downarrow \\
3.00 \mu \mathrm{M}\end{array}$ & $\begin{array}{l}620 \mathrm{~nm} \downarrow \\
6.00 \mu \mathrm{M}\end{array}$ & $\begin{array}{l}525 \mathrm{~nm} \downarrow \\
10.00 \mu \mathrm{M}\end{array}$ & $\begin{array}{l}645 \mathrm{~nm} \downarrow \\
12.00 \mu \mathrm{M}\end{array}$ & $\begin{array}{l}645 \mathrm{~nm} \downarrow \\
0.15 \pm 0.03 \mu \mathrm{M}\end{array}$ & $\begin{array}{l}525 \mathrm{~nm} \downarrow \\
0.60 \mu \mathrm{M}\end{array}$ \\
\hline
\end{tabular}

Results of the complexation of several metal ions with the fluorescent ligands under study. The maximal emission wavelength is given for the utilized excitation wavelength. The arrow indicates, if the fluorescence increases, or decreases due to quenching. Co ${ }^{2+}$ shows only a very faint decrease in fluorescence. The apparent dissociations constants, $K_{\mathrm{d}}$, were determined via linear and non-linear regression, no entry means that no significant change in the fluorescence of the dye was observed with the corresponding ion. If not noted in the table, the experimental standard deviation of the mean is below the estimated error of $5 \%$. 
dure by a digital thermoelement, which was put into the cuvette. Scan speed was $1500 \mathrm{~mm} / \mathrm{min}$; the excitation and emission slit were adjusted to a spectral bandpass of $5 \mathrm{~nm}$. We used a magnetic stirrer (position 'high' in FL Winlab) to ensure a fast mixing of the solutions added. All UV-Vis absorption spectra were recorded with a dual wavelength photometer (Aminco-Bowman DW 200).

We prepared stock solutions of the dyes, either in water (Ca Green, Fura Red, Phen Green) or in anhydrous DMSO (TSPP, TCPP, Fluo-3, Ca Crimson). Then, parts of the stock solutions were further diluted in water and sonificated for $2 \mathrm{~min}$. For optimization of the dye concentration, we recorded an intensity-concentration plot by adding small amounts of dye to water and measuring the intensity of the peaks at the characteristic emission wavelengths for each dye (see Table 1). In the range above $20 \mu \mathrm{M}$, it was more exact and more convenient to change this procedure and add small amounts of water to a concentrated dye solution. The excitation wavelengths used are also summarized in Table 1 for each dye. To avoid changes in fluorescence due to changes in the $\mathrm{pH}$, we added $10 \mathrm{mM}$ HEPES (Sigma-Aldrich, Deisenhofen, GER) and adjusted the solutions to $\mathrm{pH} 7.0$ with $1 \mathrm{M} \mathrm{NaOH}$. $\mathrm{Na}^{+}$and HEPES do not change the fluorescence of TSPP even at high concentrations, if the $\mathrm{pH}$ is held constant $(>200 \mathrm{mM}$ $\mathrm{Na}^{+},>50 \mathrm{mM}$ HEPES).

\subsection{Measurement of the dissociation constants $K_{D}$}

By adding small amounts of a stock solution of the different metals $\left(\mathrm{CuCl}_{2}, \mathrm{CoSO}_{4}, \mathrm{CdCl}_{2}, \mathrm{FeCl}_{3}, \mathrm{ZnSO}_{4}\right.$, $\mathrm{CaCl}_{2}, \mathrm{MgCl}_{2}, \mathrm{MnCl}_{2}$ ) to $2 \mathrm{ml}$ of the known $\mathrm{Ca}^{2+}$ dyes, Ca Green-1 $(0.5 \mu \mathrm{M})$, Fluo-3 $(2.5 \mu \mathrm{M})$, Fura Red $(20$ $\mu \mathrm{M})$, Ca Crimson $(2.5 \mu \mathrm{M})$ as well as to the new fluorescence probes TSPP $(10,2,0.5 \mu \mathrm{M})$, TCPP $(10$ $\mu \mathrm{M})$, Phen Green $(2 \mu \mathrm{M})$, we could determine the relation between the fluorescence, measured as an intensity at a characteristic emission wavelength (summarized in Table 1), and the concentration of the added metal. We did not add more than $20 \mu \mathrm{l}$ volume to the cuvette to avoid errors caused simply by concentration effects. After the addition of every small portion of the metal solutions, we waited before continuing to measure until there was no change in fluorescence for several minutes. Using the law of mass action, we were thus able to determine the apparent dissociation constant $K_{\mathrm{D}}$ from the measured fluorescence intensity-concentration-plot (see below) via linear and non-linear leastsquares fits. To evaluate the dynamics of the $\mathrm{Cu}^{2+}$ binding, we added $0.5,0.6$, and $10 \mu \mathrm{M} \mathrm{Cu}{ }^{2+}$ to a solution of $10 \mu \mathrm{M}$ TSPP under the same conditions as above and measured every $6 \mathrm{~s}$ the intensity at $645 \mathrm{~nm}$.

To estimate the influence of changes in the physiological $\mathrm{pH}$ range in vivo on the $K_{\mathrm{D}}$ of TSPP, we measured the dissociation constants at $\mathrm{pH}$ values between 5 and 7.4. After each measurement the $\mathrm{pH}$ of the solutions was verified $(10 \mathrm{mM}$ HEPES at $\mathrm{pH}$ values of $6.5-7.4,10$ mM MES (Sigma-Aldrich, Deisenhofen, GER) at $\mathrm{pH}$ values of 5.0-6.5). In addition, we determined the apparent $K_{\mathrm{D}}$ of TSPP for different temperatures (20$40 \pm 0.5^{\circ} \mathrm{C}$ ). Sufficient data on these relationships have already been published for all the calcium indicators (Lattanzio, 1989; Minta et al., 1989). To calculate the amount of inner filtering of TSPP and Phen Green, we measured the absorption of these dyes at the characteristic excitation wavelength and at the emission wavelength for concentrations between 0.4 and $25 \mu \mathrm{M}, 0.5$ and $10 \mu \mathrm{M}$, respectively. Further, we studied changes in the absorption when $\mathrm{Cu}^{2+}$ is added or $\mathrm{pH}$ is changed.

\subsection{Preparation of synaptosomes, measurement of the release with glutamate and $\mathrm{Ca}^{2+}$}

Synaptosomes were prepared according to the method of McMahon and Nicholls (1991). We used a sodium buffer with (in $\mathrm{mM}$ ) 10 glucose, $5 \mathrm{KCl}, 140 \mathrm{NaCl}, 5$ $\mathrm{NaHCO}_{3}, 1 \mathrm{MgCl}_{2}, 1.2 \mathrm{Na}_{2} \mathrm{HPO}_{4}, 20$ HEPES, pH 7.4. After preparation, we checked the vitality of the synaptosomes by measuring the release of glutamate (McMahon and Nicholls, 1991). We took up one pellet (1.25 mg protein) in $1 \mathrm{ml}$ buffer. After incubation in a water bath $\left(37{ }^{\circ} \mathrm{C}\right)$ for $10 \mathrm{~min}$ while stirring with a magnetic stirrer, we put the solution in a dual wavelength photometer (Aminco DW 200). We added 1.3 $\mathrm{mM} \mathrm{CaCl} 2,1 \mathrm{mM}$ NADP, $60 \mathrm{U}$ glutamate dehydrogenase. While recording the absorption simultaneously at 360 and $390 \mathrm{~nm}$, we depolarized the synaptosomes with $50 \mathrm{mM} \mathrm{KCl}$. After reaching equilibrium, we added $40 \mu \mathrm{l}$ of 20\% Triton X-100 (Sigma-Aldrich, Deisenhofen, GER), which destroys the synaptosomes and liberates huge amounts of glutamate. The crosscheck was carried out by adding $0.5 \mathrm{mM}$ EGTA instead of $\mathrm{CaCl}_{2}$ to make synaptic vesicle release impossible.

Secretion by the synaptosomes was also demonstrated by measuring intracellular $\mathrm{Ca}^{2+}$ concentrations with Fura-2-AM (Adamson et al., 1990; Whatley et al., 1995). Placing two pellets $(=2.5 \mathrm{mg}$ protein) in $2 \mathrm{ml}$ buffer solution, we incubated it with $4 \mu \mathrm{M}$ Fura-2-AM for $20 \mathrm{~min}$ at $37{ }^{\circ} \mathrm{C}$ while stirring with a magnetic stirrer. According to Whatley et al. (1995) Fura-2-AM has diffused into the cell after this period of time. However, to avoid disturbing background fluorescence, we removed the part of Fura-2-AM, which might not have diffused into the synaptosomes until then, by centrifuging for $5 \mathrm{~min}$ at $14000 \mathrm{rpm}(3000 \mathrm{~g})$ and redissolving the pellet in $37{ }^{\circ} \mathrm{C}$ buffer thereafter. In the spectrofluorometer we acquired the fluorescence excitation spectra at 340 and $380 \mathrm{~nm}$ simultaneously (emission wavelength $510 \mathrm{~nm}$ ). After recording the fluorescence blank, we added $\mathrm{CaCl}_{2}(1.3 \mathrm{mM})$, then we depolarized 
the synaptosomes with $\mathrm{KCl}(50 \mathrm{mM})$. Between each measurement, we waited some minutes for the fluorescence signal to stabilize. For a crosscheck, we used EGTA $(0.5 \mathrm{mM})$ instead of $\mathrm{CaCl}_{2}$. Control experiments were performed in the presence of botulinus toxin, which blocks synaptic vesicle release (Bruns et al., 1997).

\subsection{Measurement of exocytosis with FM 1-43}

The measurement of exocytosis was achieved with FM 1-43, a styrrol dye (Smith and Betz, 1996). We added $2 \mu \mathrm{M}$ FM $1-43$ to the preincubated solution of two pellets $(2.5 \mathrm{mg}$ protein $)$ in $2 \mathrm{ml}$ sodium buffer. We excited the fluorescence at $510 \mathrm{~nm}$ and measured the fluorescence emission at $626 \mathrm{~nm}$. After adding $\mathrm{CaCl}_{2}$ or EGTA, we depolarized the synaptosomes with $\mathrm{KCl}$ as previously in the $\mathrm{Ca}^{2+}$ measurement.

\section{6. $\mathrm{Cu}, \mathrm{Zn}$, Fe release with TSPP}

TSPP was added to preincubated synaptosomes (two pellets or $2.5 \mathrm{mg}$ protein in $2 \mathrm{ml}$ sodium buffer) in a concentration of $10 \mu \mathrm{M}$. We added the same solutions as before, but excited them at $414 \mathrm{~nm}$ and acquired the emission at 605 and $645 \mathrm{~nm}$ for measuring $\mathrm{Zn}^{2+}$ and $\mathrm{Cu}^{2+}$ release, respectively. The crosscheck was performed with EGTA and botulinus toxin instead of $\mathrm{CaCl}_{2}$, as in the experiments before.

\subsection{Validation of metal ion release by ICP-MS}

Synaptosomes were prepared and their vitality was checked by measuring the release of glutamate as described above. After depolarization $(\mathrm{KCl}, 50 \mathrm{mM})$ synaptosomes were separated from the supernatant by centrifugation $(14000 \times g)$ and the content of $\mathrm{Cu}, \mathrm{Mn}$, $\mathrm{Fe}, \mathrm{Co}, \mathrm{Ni}$, and $\mathrm{Zn}$ in the solution in comparison to the control condition without depolarization was determined.

The solutions were diluted with millipore water 1:5 and spiked with an internal ${ }^{103} \mathrm{Rh}$ standard (final concentration $10 \mu \mathrm{g} / \mathrm{l})$. The system was calibrated via serial dilutions of appropriate single and multielement standards (Merck, Darmstadt, FRG). The reported concentrations were corrected for reagent blanks. The isotopes selected were: ${ }^{65} \mathrm{Cu},{ }^{55} \mathrm{Mn},{ }^{60} \mathrm{Fe}$, and ${ }^{66} \mathrm{Zn}$. Isobaric interferences, i.e. ${ }^{37} \mathrm{Cl}^{18} \mathrm{O}$ for ${ }^{55} \mathrm{Mn}$ and ${ }^{37} \mathrm{Cl}^{14} \mathrm{~N}_{2}$ for ${ }^{65} \mathrm{Cu}$, originating from the buffer and depolarization limited the detection limit and accuracy below $1 \mu \mathrm{g} / \mathrm{l}$. However, preliminary studies revealed negligible $\mathrm{Cu}$ blanks in all reagents.

An Elan 6000 ICP-MS (Perkin-Elmer, Sciex, Toronto, Canada) was employed in combination with a conventional cross flow nebulizer, a peristaltic pump for sample introduction, and an AS-91 autosampler. We used a $\mathrm{Rf}$ power of $1100 \mathrm{~W}$, a sample uptake of $1 \mathrm{ml} / \mathrm{min}$ and wash time of 4 min after each sample, a nebulizer gas flow of $0.8 \mathrm{l} / \mathrm{min}$, and a dwell time per mass of 100 $\mathrm{ms}$ with 40 scans per sample and five replicates. Quality control was established by evaluation of aqueous solutions of multielement standards and matrix matched (see above) aqueous solutions of these standards.

\subsection{Estimation of $K_{D}$}

The dissociation of a complex with a dye and $n$ metal ions $\left[\right.$ dye - metal $\left._{n}\right]$ is given by

$\left[\right.$ dye - metal $\left._{n}\right] \stackrel{K_{\mathrm{d}}}{\leftrightarrow}$ dye $+n \cdot$ metal

According to the law of mass action the corresponding dissociation constant $K_{\mathrm{D}}$ is determined by

$K_{\mathrm{d}}=\frac{[\text { dye }] \cdot[\text { metal }]^{n}}{\left[\text { dye }- \text { metal }_{n}\right]}$

where [dye], [metal], [dye - metal $_{n}$ ] are the concentrations of the dye, the metal ion, and the complex, respectively. $K_{\mathrm{d}}$ refers to the formation of an (association) complex with quenched or enhanced fluorescence, the measured constants are therefore apparent dissociation constants under the experimental conditions not the thermodynamic equilibrium values. Given the total concentration of the dye $[\text { dye }]_{t}=[$ dye $]+\left[\right.$ dye - metal $\left._{n}\right]$, we can calculate the fraction of complexed dye $f$ :

$f=\frac{\left[\text { dye }- \text { metal }_{n}\right]}{[\text { dye }]_{t}}=\frac{[\text { metal }]^{n}}{K_{\mathrm{d}}+[\text { metal }]^{n}}$.

For TSPP, the fluorescence $F$ decreases by adding copper from its maximum value $F_{\max }$, when $\left[\mathrm{Cu}^{2+}\right]=$ 0 , down to $F_{\min }=0$. With $n=1$, we get:

$F=F_{\text {max }}-\left(F_{\text {max }}-F_{\text {min }}\right) \cdot \frac{\left[\mathrm{Cu}^{2+}\right]}{\left[\mathrm{Cu}^{2+}\right]+K_{\mathrm{d}}}$

and

$\left[\mathrm{Cu}^{2+}\right]=K_{\mathrm{d}} \cdot \frac{(1-r)}{r}$ with $r=\frac{F}{F_{\max }}$

$\frac{F_{\max }}{F}=1+K_{\mathrm{d}}^{-1}[Q]$,

and $\left[\mathrm{Cu}^{2+}\right]$ the concentration of copper ions. Eq. (4a) is equivalent to the well known Stern-Volmer (SV) Eq. (4b) for dynamic or static quenching of a fluorphore. The quencher concentration $[\mathrm{Q}]$ is here equivalent to [metal] and whereas $K_{\mathrm{d}}^{-1}$ corresponds to the SV constant. Similarly, we can calculate the concentration of zinc ions $\left[\mathrm{Zn}^{2+}\right]$, taking into account that the fluorescence of TSPP increases this time: 
$\left[\mathrm{Zn}^{2+}\right]=$

$\frac{\left(r^{\prime}-1\right) \cdot F_{\min } \cdot K_{\mathrm{d}}}{\left(F_{\max }-F_{\min }\right)\left(1-F_{\min } \cdot\left(\left(r^{\prime}-1\right) /\left(F_{\max }-F_{\min }\right)\right)\right)}$,

with $r^{\prime}=F / F_{\max }$.

\subsection{Measurement of $\left[\mathrm{Ca}^{2+}\right]$}

The concentration of calcium can be calculated from (Grynkiewicz et al., 1985):

$\left[\mathrm{Ca}^{2+}\right]=K_{\text {eff }} \cdot \frac{R-R_{\min }}{R_{\max }-R}$,

with the ratio of the fluorescence excitation spectra $R=$ excitation at $340 \mathrm{~nm} /$ excitation at $380 \mathrm{~nm}$. $\quad R_{\max } /$ $R_{\min }$ are the values of $R$ with maximal and minimal concentration of $\mathrm{Ca}^{2+}$ and

$K_{\text {eff }}=S \cdot K_{\mathrm{d}}$.

$S$ is the ratio of the excitation spectrum at $380 \mathrm{~nm}$ at zero $\left[\mathrm{Ca}^{2+}\right]$ and the excitation spectrum at $380 \mathrm{~nm}$ at maximum $\left[\mathrm{Ca}^{2+}\right]$. The values $K_{\text {eff }}, R_{\min }$, and $R_{\max }$ can be determined easily by a calibration experiment, explained in detail by Grynkiewicz et al. (1985).

\subsection{Estimation of copper content of synaptic vesicles}

FM 1-43 exhibits a fluorescence, which rises proportionally with the increase of membrane area due to exocytosis. Thus,

$f_{\mathrm{FM}}-1=\frac{F_{\text {after }}}{F_{\text {before }}}-1=\frac{A_{\text {vesicle }}}{A_{\text {synaptosome }}}=\frac{n_{\text {vesicle }} \cdot d_{\text {vesicle }}^{2}}{d_{\text {synaptosome }}^{2}}$,

with $f_{\mathrm{FM}}=F_{\text {after }} / F_{\text {before }}$ the ratio of fluorescence emission before and after depolarization, $A_{\text {vesicle and }}$ $A_{\text {synaptosome }}=$ area of one vesicle and one synaptosome, respectively, $d_{\text {vesicle }}$ and $d_{\text {synaptosome }}=$ diameter of a vesicle and a synaptosome, respectively, $n_{\text {vesicle }}=$ mean number of vesicles in one synaptosome. We can estimate the total $\mathrm{Cu}$ concentration in a synaptic vesicle $[\mathrm{Cu}]_{\text {vesicle }}$ with the result of the FM-1-43-measurement by determining the change in the $[\mathrm{Cu}]$ concentration of a solution of synaptosomes before and after depolarization in a cuvette (volume of the solution is $V$ ), if the number of synaptosomes $n_{\text {synaptosomes }}$ is known:

$$
\begin{aligned}
& {[\mathrm{Cu}]_{\text {vesicle }}=\frac{[\mathrm{Cu}] \cdot V}{n_{\text {synaptosomes }} \cdot n_{\text {vesicle }} \cdot(4 / 3) \cdot \pi \cdot\left(d_{\text {vesicle }} / 2\right)^{3}}} \\
& =\frac{1}{n_{\text {synaptosomes }}} \cdot \frac{[\mathrm{Cu}]}{\left(f_{\mathrm{FM}}-1\right)} \cdot \frac{V}{d_{\text {synaptosomes }}^{2} \cdot d_{\text {vesicle }} \cdot(1 / 6) \cdot \pi} .
\end{aligned}
$$

The number of synaptosomes in our solution should be about proportional to the measured protein content, which was constant in every experiment, except in Fig. $5 \mathrm{~F}$. The last part of Eq. (9) is constant on the average, with about $0.6 \mu \mathrm{m}$ for $d_{\text {synaptosomes }}, 0.06 \mu \mathrm{m}$ for $d_{\text {vesicle }}$ (Dunkley et al., 1986, 1988) and $V=2 \mathrm{ml}$. In total, the concentration of copper ions in synaptic vesicles is proportional to the measured concentration $[\mathrm{Cu}]$ in the cuvette after release divided by the increase of fluorescence $f-1$ of FM 1-43. We assume the protein content p.c. to be proportional to $n_{\text {synaptosomes }}$, connected by the constant $\rho_{\text {synaptosomes, }}$, which represents the mean protein weight per synaptosome. Thus we find, using

$n_{\text {synaptosome }}=\frac{\text { p.c. } \cdot V}{\rho_{\text {synaptosome }}}$,

for the copper concentration in the synaptic vesicle:

$$
\begin{aligned}
{[\mathrm{Cu}]_{\text {vesicle }}=} & \frac{\rho_{\text {synaptosome }}}{\text { p.c. }} \cdot \frac{[\mathrm{Cu}]}{\left(1-f_{\mathrm{FM}}\right)} \\
& \cdot \frac{1}{d_{\text {synaptosomes }}^{2} \cdot d_{\text {vesicle }} \cdot(1 / 6) \cdot \pi} .
\end{aligned}
$$

\subsection{Estimation of copper binding to proteins}

Normally, most of the copper is bound to proteins, like ceruloplasmin (Brown et al., 1997). Thus, the equilibrium after addition of TSPP is represented by

$\mathrm{TSPP}-\mathrm{Cu}+$ Protein $\leftrightarrow$ Protein $-\mathrm{Cu}+\mathrm{TSPP}$

As TSPP is only sensitive to $\mathrm{Cu}^{2+}$, while copper is mostly bound to proteins as $\mathrm{Cu}^{+}$, we have to assume a fast oxidation step of $\mathrm{Cu}^{+}$after release before binding to TSPP. Then, the simplified dissociation constant $K_{\mathrm{d}}$ of this reaction is

$K_{\mathrm{d}}=\frac{[\text { Protein }-\mathrm{Cu}] \cdot[\mathrm{TSPP}]}{[\mathrm{TSPP}-\mathrm{Cu}] \cdot[\text { Protein }]}$

This gives with the dissociation constants of the partial reactions, $K_{\text {Protein }}$ and $K_{\mathrm{TSPP}}$ :

$$
\begin{aligned}
& \text { Protein }-\mathrm{Cu} \leftrightarrow \text { Protein }+\mathrm{Cu} \rightarrow K_{\text {protein }} \\
& \quad=\frac{[\text { Protein }] \cdot[\mathrm{Cu}]}{[\text { Protein }-\mathrm{Cu}]} \\
& \mathrm{TSPP}-\mathrm{Cu} \leftrightarrow \mathrm{TSPP}+\mathrm{Cu} \rightarrow K_{\mathrm{TSPP}} \\
& \quad=\frac{[\mathrm{TSPP}] \cdot[\mathrm{Cu}]}{[\mathrm{TSPP}-\mathrm{Cu}]}
\end{aligned}
$$

so $K_{\mathrm{D}}=K_{\mathrm{TSPP}} / K_{\text {Protein }}$. Using $f_{\mathrm{TSPP}}=[\mathrm{TSPP}-\mathrm{Cu}] /$ $[\mathrm{TSPP}]_{t}$, this yields:

$$
\frac{K_{\mathrm{TSPP}}}{K_{\text {Protein }}}=\frac{[\text { Protein }-\mathrm{Cu}] \cdot\left([\mathrm{TSPP}]_{t}-[\mathrm{TSPP}-\mathrm{Cu}]\right)}{[\text { Protein }] \cdot[\mathrm{TSPP}-\mathrm{Cu}]}
$$




$$
\begin{aligned}
& =\frac{[\text { Protein }-\mathrm{Cu}]}{[\text { Protein }] \cdot f_{\mathrm{TSPP}}}-\frac{[\text { Protein }-\mathrm{Cu}]}{[\text { Protein }]} \\
& =\frac{[\text { Protein }-\mathrm{Cu}]}{[\text { Protein }]} \cdot\left(\frac{1}{f_{\mathrm{TSPP}}}-1\right) \\
& \left(\frac{[\text { Protein }]_{t} \cdot[\text { Protein }-\mathrm{Cu}]}{[\text { Protein }-\mathrm{Cu}]}\right)^{-1}\left(\frac{1}{f_{\mathrm{TSPP}}}-1\right) \\
& =\left(f_{\text {Protein }}^{-1}-1\right)^{-1} \cdot\left(\frac{1}{f_{\mathrm{TSPP}}}-1\right)
\end{aligned}
$$

$[\mathrm{TSPP}]_{t}$ and [Protein $]_{t}$ represent the total concentrations of TSPP and the protein, respectively; $f_{\text {Protein }}=$ $[$ Protein $-\mathrm{Cu}] /[\text { Protein }]_{t}$.

\section{Results}

First, we analyzed the characteristics of the dyes, starting with the excitation, respectively the absorption of TSPP and Phen Green. The corresponding values of the $\mathrm{Ca}^{2+}$ indicators are already sufficiently described in the literature (Kao, 1994; Haughland, 1996).

\subsection{Absorption of TSPP and Phen Green}

TSPP is characterized by a considerable molar extinction coefficient, which is typical for the phorphyrins in general (Falk, 1975; Biesaga et al., 2000 and references therein). At the utilized excitation wavelength $\lambda=414 \mathrm{~nm}$ (Soret band) we found an extinction coefficient of $\varepsilon_{414 \mathrm{~nm}}=427000 \pm 42000$ at the emission wavelength $\lambda=645 \mathrm{~nm} \varepsilon_{645 \mathrm{~nm}}=47000 \pm 2700$ (Fig. 1A with nine measurements), so that the inner filtering effect is probably the reason why the fluorescence intensity vs. concentration plot shown in Fig. 1B shows a non-linear behavior above $[\mathrm{TSPP}]_{\tau}=0.8 \mu \mathrm{M}$. With the value of $\varepsilon$ it is possible to calculate a correction factor compensating for the inner filtering. However, absorbance at $\lambda=414$ and $645 \mathrm{~nm}$ is only dependent on the $\mathrm{pH}$, while the dependence upon the small shift in the absorption spectrum (see Fig. 2C) with the addition of $\mathrm{Cu}^{2+}$ can be neglected. Thus, the influence of inner filtering is the same for $F$ as for $F_{\max }$ and can be neglected, if ratios are used for calculating $\left[\mathrm{Cu}^{2+}\right]$. Phen Green is excited best at $488 \mathrm{~nm}$. Although the absorbance at the excitation wavelength for a concentration of $2 \mu \mathrm{M}$ is already $A=0.125$ according to Fig. $1 \mathrm{C}$, the inner filter effect is not very significant and the correction factor is calculated to be $k=1.10$.
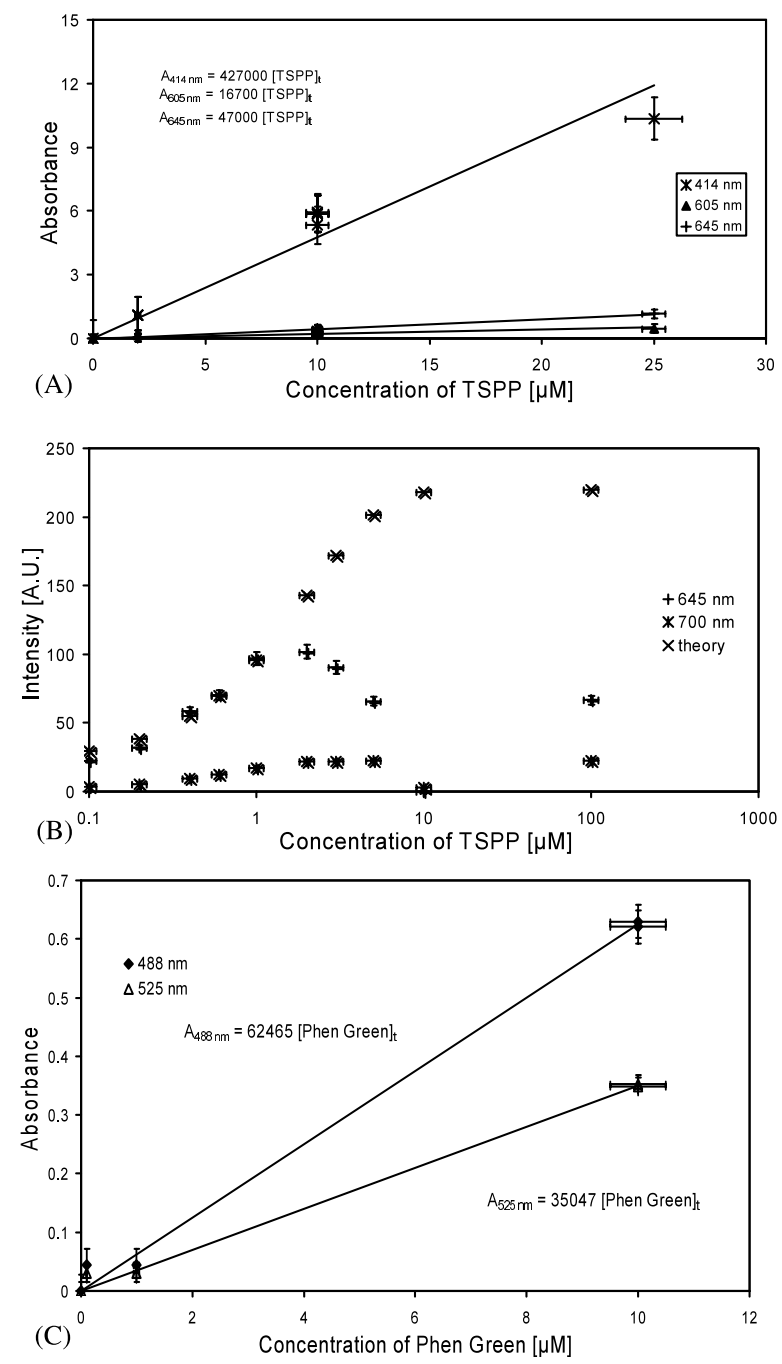

Fig. 1. Absorption of TSPP and Phen Green. (A) Increase of absorption of TSPP at different wavelengths (nine values for each wavelength) by adding small amounts of the dye at $\mathrm{pH} 7.0$ and $T=$ $37{ }^{\circ} \mathrm{C}$. (B) Variation of intensity at different emission wavelengths (excitation at $414 \mathrm{~nm}$ ) with concentration of TSPP. The theoretical curve was derived taking into account a correction factor for the inner filter effect according to Hoppe et al. (1982). The error bars indicate the estimated dilution error of 5\%. (C) As (A) with Phen Green (five values for each wavelength). The error bars for the ordinate in $\mathrm{A}-\mathrm{C}$ indicate the mean and standard error. The error in concentration of $5 \%$ represents deviations due to dilution of the dye.

\subsection{Spectrum of the dyes}

The fluorescence emission spectra of the most promising copper ligands are summarized in Fig. 2A. TSPP and TCPP have similar excitation and emission spectra, both are excited best at $414 \mathrm{~nm}$ and have a fluorescence peak at $645 \mathrm{~nm}$ with a shoulder at around $700 \mathrm{~nm}$. Phen Green displayed at the emission maximum of $525 \mathrm{~nm}$ a very bright fluorescence compared to similar concentrations of TSPP (Fig. 2A). 

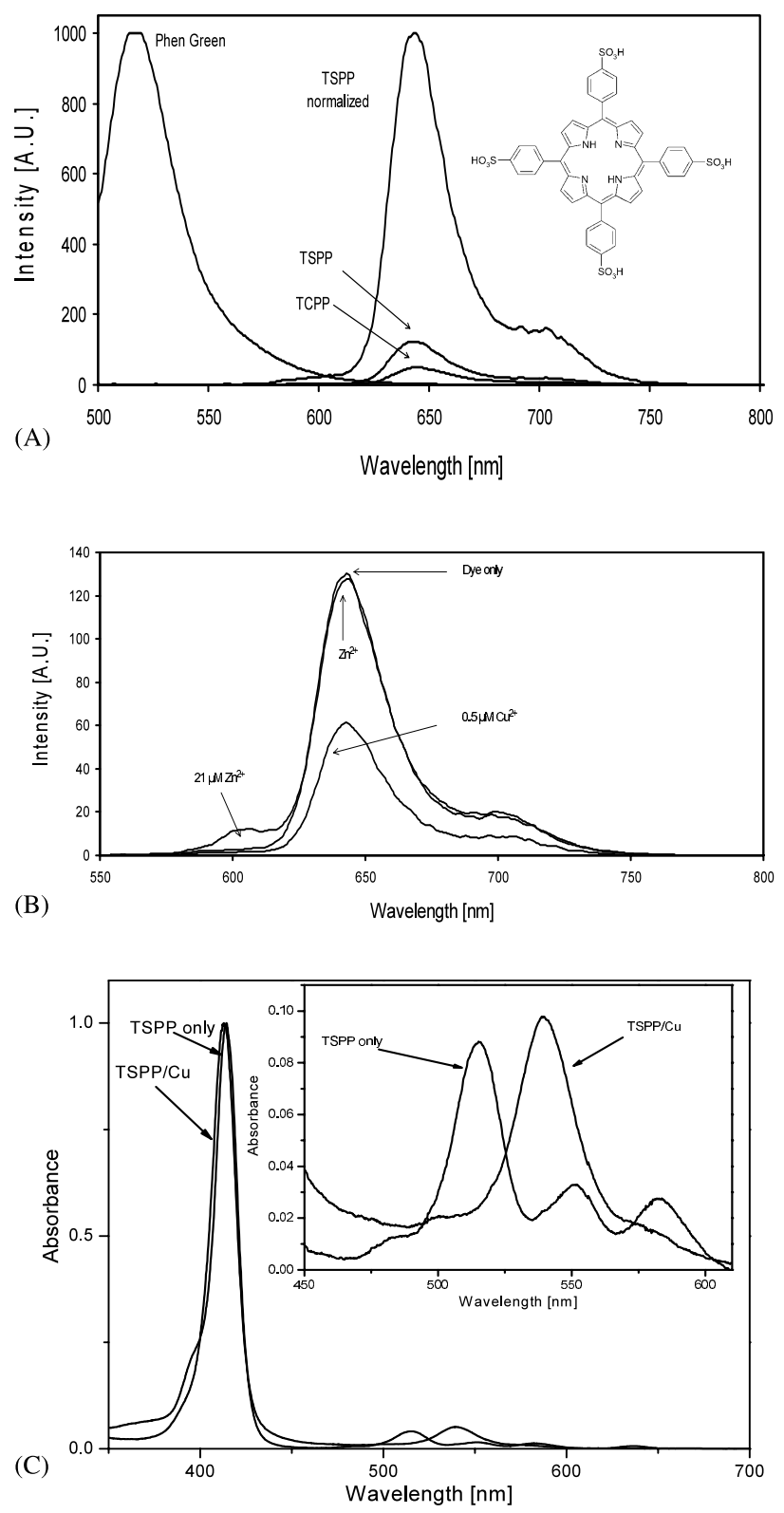

Fig. 2. Spectra of TSPP and Phen Green. (A) Spectra of $2 \mu \mathrm{M}$ TSPP, $10 \mu \mathrm{M}$ TCPP and $2 \mu \mathrm{M}$ Phen Green at the corresponding maximal excitation wavelength shown in Table 1 . The spectrum of TSPP was normalized to yield the same maximal intensity as Phen Green. The inlay shows the chemical structure of TSPP. (B) Already $0.5 \mu \mathrm{M} \mathrm{Cu}^{2+}$ cause a decrease of fluorescence at the $645 \mathrm{~nm}$ peak and also of the 700 $\mathrm{nm}$ shoulder, but there is practically no influence on the region around $605 \mathrm{~nm}$. On the other side, $\mathrm{Zn}^{2+}(21 \mu \mathrm{M}-40$ times the concentration of $\mathrm{Cu}^{2+}$ - in this case) gives a significant increase of fluorescence at $605 \mathrm{~nm}$, which does not affect the fluorescence maximum at $645 \mathrm{~nm}$. For reference, we added the spectrum of the pure TSPP-solution. (C) Changes in the absorption spectrum of TSPP $(4 \mu \mathrm{M})$ after complexation with copper $(2 \mu \mathrm{M})$. The intensities were normalized by the peak at $645 \mathrm{~nm}$. The inlay magnifies the part of the spectrum around 525 $\mathrm{nm}$. Here one can see a faint shift in the absorption wavelength upon increase of copper concentration.

\subsection{Dissociation constants, dynamics, $p H$ - and temperature-dependence of fluorescence}

The apparent dissociation constants were determined as described above via linear and non-linear regression analysis and are summarized in Table 1. TSPP did not react to even high amounts of $\mathrm{Ca}^{2+}$ and $\mathrm{Mg}^{2+}$. Taking into account the thermodynamic equilibrium constants reported by Jimenez et al. (1991), we can safely assume that the reaction is probably too slow under the experimental conditions ( $\mathrm{pH}$-value and aqueous system).

Further, difficulties can arise by geometric considerations as only cations with a ionic radius between 60 and $70 \mathrm{pm}$ can fit into the porphyrin ring. Larger cations such as $\mathrm{Cd}^{2+}$ and $\mathrm{Ca}^{2+}$ can only form an out-of-plane complex on top of the molecule (see Falk, 1975; Tanaka, 1983; Turay and Hambright, 1980). There was a comparably weak interaction with $\mathrm{Fe}^{3+}$, decreasing the fluorescence at $645 \mathrm{~nm}\left(K_{\mathrm{D}}=12 \pm 0.6 \mu \mathrm{M}\right.$, Fig. $3 \mathrm{~B})$. The increase caused by addition of $\mathrm{Co}^{2+}\left(K_{\mathrm{d}}=\right.$ $0.2 \pm 0.1 \mu \mathrm{M}$ ) was almost negligible (Fig. 3C) andcontrary to the information of Molecular Probes (Haughland, 1996) - no changes were to be seen with $\mathrm{Cd}^{2+}$ (Fig. 3D) and $\mathrm{Mn}^{2+}$, probably again due to the slow formation of the sterically not favorable complexes. $\mathrm{Zn}^{2+}$ caused a strong increase in fluorescence at $605 \mathrm{~nm}\left(K_{\mathrm{d}}=50 \pm 2.5 \mu \mathrm{M}\right)$, while $\mathrm{Cu}^{2+}$ quenched its fluorescence at $645 \mathrm{~nm}$ completely with a $K_{\mathrm{d}}$ of $0.43 \pm$ $0.07 \mu \mathrm{M}$ (Fig. 3A). The linear regression of our data (taken from Fig. 3A) to Eq. (4a), which is equivalent to a Stern-Volmer plot (Fig. 3B), was highly linear $\left(r^{2}=\right.$ 0.94 ) and indicated a pure dynamic or static quench process. The quenching of the fluorescence by $\mathrm{Cu}^{2+}$ is related to its paramagnetic electronic configuration $\left([\mathrm{Ar}] 3 \mathrm{~d}^{9}\right)$, which increases triplet transitions and results in a reduction of fluorescence from the TSPP molecule. The ionic radius of $\mathrm{Zn}^{2+}(73 \mathrm{pm})$ permits also a fit into the porphyrin nucleus, the increase in fluorescence is probably due to the reduction of internal conversion processes by the gain in structural rigidity of TSPP upon complexation. The increase at $605 \mathrm{~nm}$, though, had no effect on the fluorescence at $645 \mathrm{~nm}$ (Fig. 2B). The size of $\mathrm{Cu}^{2+}$ (ionic radius of $73 \mathrm{pm}$ ) is sufficient to fit into the porphyrin nucleus of TSPP, while the ionic radius of $\mathrm{Cu}^{+}(91 \mathrm{pm})$ does not allow a complex formation. Jimenez et al. (1991) reported only a small shift of $1 \mathrm{~nm}$ in the absorption spectrum on complexation of copper (80:20 mixture of DMSO-water). Fig. 2C reveals this small shift from 414 to $413 \mathrm{~nm}$ upon complexation of TSPP with $\mathrm{Cu}^{2+}$. Significant changes are observed between 500 and $600 \mathrm{~nm}$. The complexation leads to a new band at $539 \mathrm{~nm}$ and the disappearance of the band at $515 \mathrm{~nm}$ which support the formation of the complex. This shift was also observed by Jimenez et al. (1991), however under different conditions. The two other 

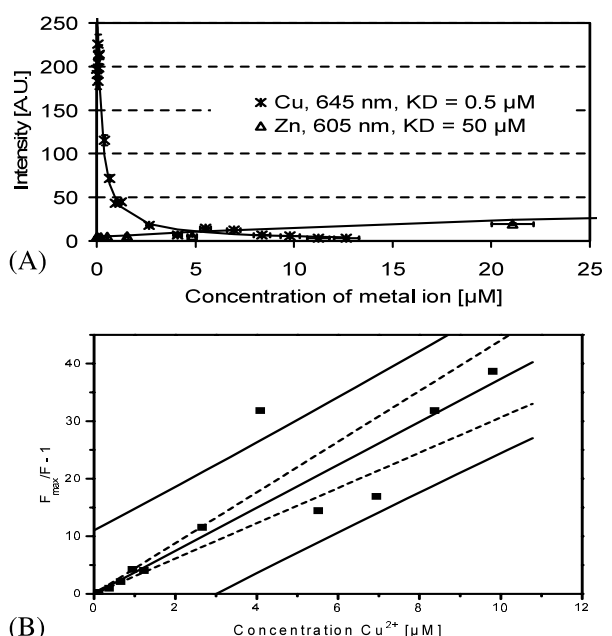

(B)
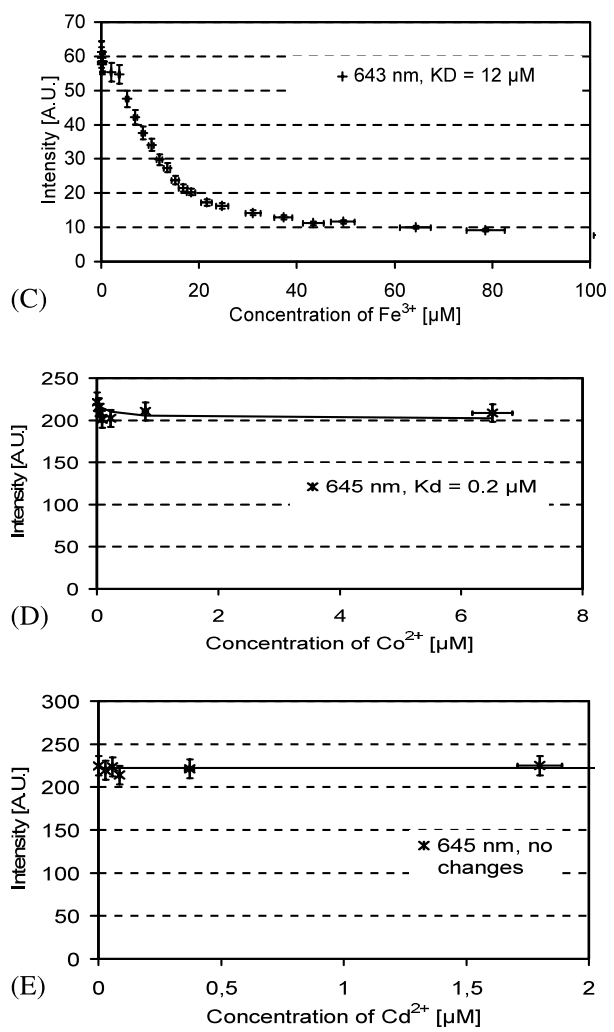

Fig. 3. Change of fluorescence of TSPP as a consequence of quenching by different metal ions. Change of fluorescence of TSPP as a consequence of quenching by (A) $\mathrm{Cu}^{2+}, \mathrm{Zn}^{2+}$, (C) $\mathrm{Fe}^{3+}$, (D) $\mathrm{Co}^{2+}$ and (E) $\mathrm{Cd}^{2+}$ ions; excitation at $414 \mathrm{~nm}$, emission wavelengths as shown. (B) shows the corresponding Stern-Volmer plot (see Eq. (4b)) for $\mathrm{Cu}$ /TSPP $\left(r^{2}=0.94\right)$. Via linear and non-linear regression the following apparent dissociation constants were determined: $K_{\mathrm{d}}=$ $0.43 \pm 0.07 \mu \mathrm{M}$ at $645 \mathrm{~nm}$ for $\mathrm{Cu}^{2+}, K_{\mathrm{d}}=50 \pm 2.5 \mu \mathrm{M}$ at $605 \mathrm{~nm}$ for $\mathrm{Zn}^{2+}, K_{\mathrm{d}}=12 \pm 0.6 \mu \mathrm{M}$ at $645 \mathrm{~nm}$ for $\mathrm{Fe}^{3+}, K_{\mathrm{d}}=0.2 \pm 0.1 \mu \mathrm{M}$ for $\mathrm{Co}^{2+}$. No significant changes were to be seen upon addition of $\mathrm{Cd}^{2+}$ ions. The error bars for the ordinate of $\mathrm{A}-\mathrm{D}$ indicate the mean and standard error, respectively, of three different measurements. The error in concentration of $5 \%$ represents deviations due to dilution of the metal ions. bands at 551 and $582 \mathrm{~nm}$ are overlapped with the strong peak at $539 \mathrm{~nm}$. The formation of the complex is relatively fast, compared e.g. to the $\mathrm{Zn}$ complex as already described by Turay and Hambright (1980), and verified by Fig. 5E.

With the $K_{\mathrm{d}}$ being approximately $0.5 \mu \mathrm{M}$ for $\mathrm{Cu}^{2+}$ it is recommended that at least $5 \mu \mathrm{M}$ of the dye is used to capture a representative amount of the added $\mathrm{Cu}^{2+}$ ions. This concentration, on the other hand, is already associated with a very high absorbance $(A=2.39)$ and as a consequence inner filtering, which can result in artifacts if the filter effect is not compensated. The $\mathrm{Zn}^{2+}$ concentration can be determined from Eq. (5). In contrast to TSPP, the other $\mathrm{Cu}^{2+}$ indicators Phen Green and TCPP showed much poorer specificity to
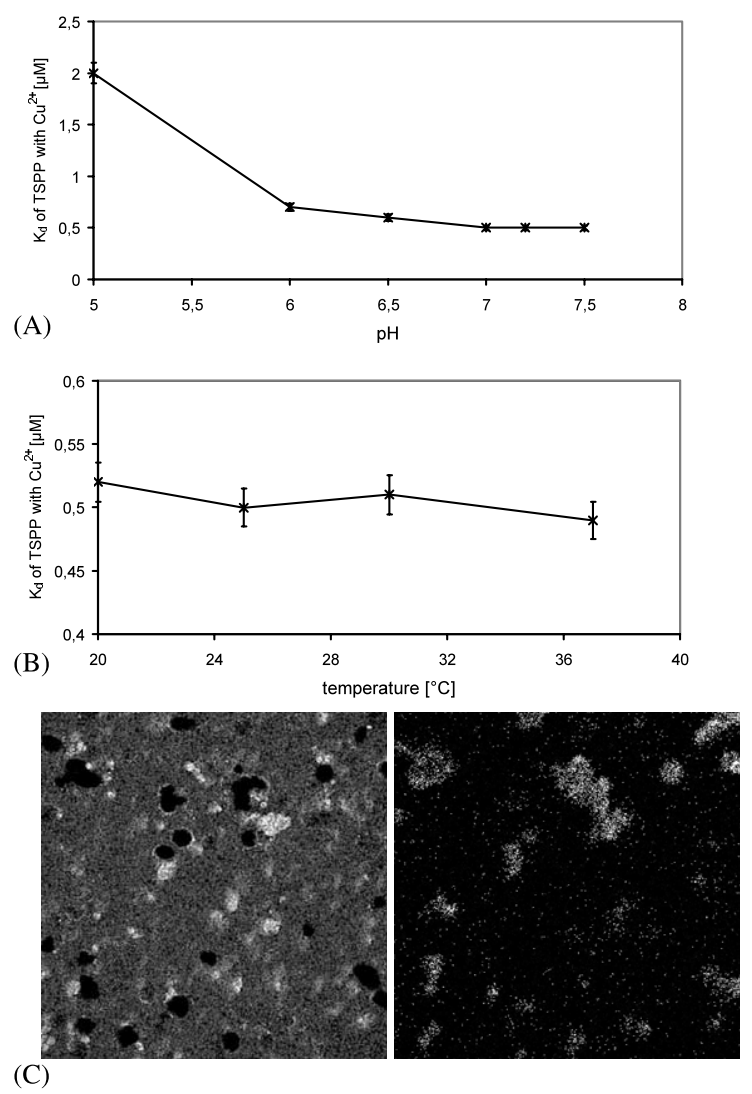

Fig. 4. Dependence of dissociation constant of TSPP with $\mathrm{Cu}^{2+}$ on $\mathrm{pH}$ and temperature, cell permeability. (A) The dissociation constant $K_{\mathrm{d}}$ of TSPP with $\mathrm{Cu}^{2+}$ changes significantly with $\mathrm{pH}$, when $\mathrm{pH}<6.0$. As in Fig. 1, the error bars indicate mean and standard error of three different measurements. The $\mathrm{pH}$ value was measured with a standard $\mathrm{pH}$-meter, which has an error of $\Delta \mathrm{pH} \pm 0.2$. (B) Within the temperature range of $20-37{ }^{\circ} \mathrm{C}$ the $K_{\mathrm{d}}$ of TSPP with $\mathrm{Cu}^{2+}$ seems to be roughly constant. The temperature was measured with a digital thermo element (error $\Delta t= \pm 0.5^{\circ} \mathrm{C}$ ). It was held constant by a water circuit inside the LS 50 spectrometer. The experiment was conducted in the same way as in (A). (C) Confocal microscope image exhibiting the autofluorescence of bovine chromaffin cells at $510-525 \mathrm{~nm}$ on the right and on the left at $700 \pm 40 \mathrm{~nm}$ the fluorescence of $10 \mu \mathrm{M}$ TSPP, only to be found outside the cells, after about an hour of incubation. The fluorescence was excited by a $488 \mathrm{~nm}$ Ar-Ion laser. 

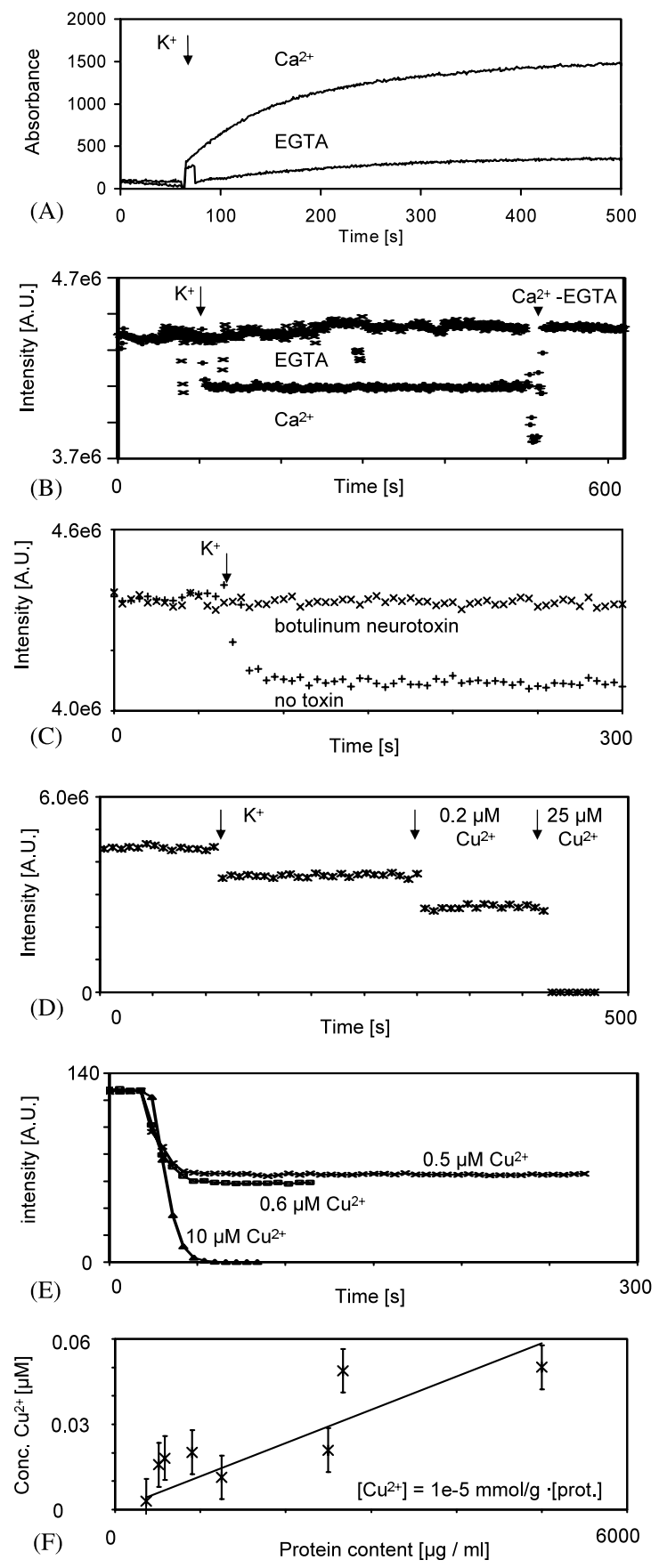

Fig. 5

the $\mathrm{Cu}^{2+}$ ion. TCPP was quenched by all of the examined metals except $\mathrm{Mg}^{2+}$. Phen Green reacted similarly, but was not affected by $\mathrm{Ca}^{2+}$. We also found many calcium indicators which are significantly quenched by $\mathrm{Cu}^{2+}$, e.g. Ca Crimson and Fluo-3 (cf. Table 1).

No significant changes of $K_{\mathrm{d}}\left(\mathrm{Cu}^{2+}\right)$ with respect to temperature was observed for temperatures between 20 and $37{ }^{\circ} \mathrm{C}$, as indicated in Fig. 4A. This observation strongly points to a static quench process as the $\mathrm{SV}$ constant and albeit $K_{\mathrm{d}}$ should increase with increasing temperature in case of dynamic (collisional) quenching (Lakowicz, 1999). Further, the $\mathrm{pH}$ causes the increase of $K_{\mathrm{d}}\left(\mathrm{Cu}^{2+}\right)$, when reduced below 6.0 (Fig. 4B) which agrees with earlier findings (Jimenez et al., 1991; Turay and Hambright, 1980).

\subsection{Membrane permeability of TSPP}

TSPP does not penetrate the cell membrane of bovine chromaffin cells. Even after an incubation time of $1 \mathrm{~h}$, no fluorescence from TSPP was observed within the chromaffin cells. At the places where the cells were observed with bright field illumination, we found bright dots at 500 (autofluorescence of the chromaffin cells), and at $700 \mathrm{~nm}$ we found black dots with a bright background (see Fig. 4C) showing TSPP fluorescence only outside of the cells.

\subsection{Synaptosomal copper release studied with TSPP}

In order to study copper release after exocytosis using TSPP, we performed functional studies on synaptosomes. Thirty-seven nerve terminal preparations were performed as described in Section 2. The quality of every preparation was analyzed by measuring spectrophotometrically glutamate release following the reduction of NADP by glutamate dehydrogenase (see Section 2). One example is shown in Fig. 5A. Copper measurements were carried out by preincubating the synapto-

Fig. 5. Synaptosomal $\mathrm{Cu}$ release studied with TSPP. (A) In order to monitor the vitality of the synaptosomal preparations, glutamate release was studied spectrophotometrically following the reduction of NADP by glutamate dehydrogenase. Incubation was performed in the presence of $\mathrm{Ca}^{2+}\left(1.3 \mathrm{mM} \mathrm{Ca}^{2+}\right)$ or in the absence of $\mathrm{Ca}^{2+}$ and the presence of EGTA. The arrow indicates the addition of $50 \mathrm{mM} \mathrm{KCl}$ to synaptosomes of mice. In the presence of $\mathrm{Ca}^{2+}$, depolarization leads to an increase in absorbance, indicating glutamate release. (B) Synaptosomes, in the presence of TSPP $(10 \mu \mathrm{M})$, were depolarized with $\mathrm{KCl}$ $(50 \mathrm{mM})$ at the time point indicated. At $500 \mathrm{~s}$ indicated by an arrowhead we removed all $\mathrm{Cu}$ ions with Ca-EGTA $(10 \mathrm{mM})$. As a crosscheck, $\mathrm{Ca}^{2+}$ was left out in the buffer. Instead we added $0.5 \mathrm{mM}$ EGTA. (C) Same measurement as in B, but the crosscheck was made by adding botulinus neurotoxin to the normal $\mathrm{Ca}^{2+}$ containing buffer solution before depolarization. The time scale is focused on the moment of depolarization. (D) Measured as in $\mathrm{B}$ and $\mathrm{C}$ in the presence of $\mathrm{Ca}^{2+}$ but depolarizing of the synaptosomes was followed by the addition of $0.2 \mu \mathrm{M} \mathrm{Cu}^{2+}$. The kinetics is very similar to the depolarization-induced quenching of TSPP. Further addition of $25 \mu \mathrm{M}$ $\mathrm{Cu}^{2+}$ completely quenches the dye. (E) We added $0.5,0.6$, and $10 \mu \mathrm{M}$ $\mathrm{Cu}^{2+}$ to a solution of $10 \mu \mathrm{M}$ TSPP (without synaptosomes) under conditions similar to those of Fig. 3 and measured every $6 \mathrm{~s}$ the intensity at $645 \mathrm{~nm}$ to show the time dependence of the $\mathrm{Cu}^{2+}$-binding. (F) Analysis of the influence of the amount of synaptosomes, represented by the protein content, on the amount of $\mathrm{Cu}$ released, each measured with $10 \mu \mathrm{M}$ TSPP as in B-D. The linear regression yields: $1.0 \pm 0.3 \times 10^{-5} \mathrm{mmol} \mathrm{Cu} / \mathrm{g}$ protein used. This indicates that the measured changes in $\mathrm{Cu}$ concentration are indeed a consequence of synaptosomal release. 
somes for $5 \mathrm{~min}$ and applying $10 \mu \mathrm{M}$ TSPP to the solution. Depolarization of the synaptosomes leads to a significant decrease in fluorescence, indicating copper release (Fig. 5B). Although the diamagnetic $\mathrm{Cu}^{+}$ion $\left([\mathrm{Ar}] 3 \mathrm{~d}^{10}\right)$ is not uncommon in protein-copper complexes, the strong fluorescence quenching is caused by the paramagnetic $\mathrm{Cu}^{2+}$, so that we can safely assume that in vivo observations are due to $\mathrm{Cu}^{2+}$. No decrease was observed in the presence of EGTA, indicating that copper indeed was released when synaptic vesicle release takes place (see Fig. 5B). The complex formation (i.e. $K_{\mathrm{d}}^{-1}$ ) for $\mathrm{Cu}^{2+}$ and EGTA is in the order $10^{18}$, so that the copper is preferentially bound to the EGTA after release. The same results were observed with synaptosomes preincubated with botulinum neurotoxin, which is known to block synaptosomal release (Fig. 5C). For a semiquantitative estimation of the amount of copper released from the synaptosomes, $0.2 \mu \mathrm{M} \mathrm{Cu}{ }^{2+}$ was added after depolarization, Fig. 5D depicts that the standard addition yielded a kinetic similar to the estimated copper concentration reached in the cuvette when synaptosomes are depolarized; an additional 25 $\mu \mathrm{M} \mathrm{CuCl}{ }_{2}$ quenched the fluorescence completely. The released copper concentration was determined via Eq. (4a), with the known volume of the solution $(2 \mathrm{ml})$ the absolute amount of copper was calculated. The released amount of copper was found to depend significantly upon the protein content in the synaptosomal preparations (Fig. 5F), so that p.c. (compare Eq. (11)) was used for normalization. The fit (linear regression) gives the relation:

$\left[\mathrm{Cu}^{2+}\right]=1.0 \pm 0.3 \times 10^{-5}\left[\frac{\mathrm{mmol} \mathrm{Cu}^{2+}}{\mathrm{g} \text { protein used }}\right]$

-protein content

The amount of copper released with depolarization of synaptosomes measured with the fluorophore $(0.9 \pm 0.1$ $\mathrm{ng} / \mathrm{mg}$ protein) is in the order of $25 \%$ of the amount of copper measured with ICP-MS $(3.9 \pm 1.0 \mathrm{ng} / \mathrm{mg}$ protein). The ICP-MS measurements revealed also elevated concentrations of iron after depolarization $(6.4 \pm 2.8 \mathrm{ng}$ $\mathrm{Fe} / \mathrm{mg}$ protein). Due to the considerable difference of the dissociation constants, the iron content had a negligible influence on the TSPP quenching by copper. Further, we found a significant rise in $\mathrm{Zn}$ after depolarization of $20.1 \pm 5.5 \mathrm{ng} \mathrm{Zn} / \mathrm{mg}$ protein with TSPP and $15.7 \pm 5.8 \mathrm{ng} \mathrm{Zn} / \mathrm{mg}$ protein with ICP-MS (Fig. 6).

\section{Discussion}

There is increasing evidence that copper ions play an important role in several neurodegenerative diseases such as Alzheimer's disease and CJD (Bush, 2000).
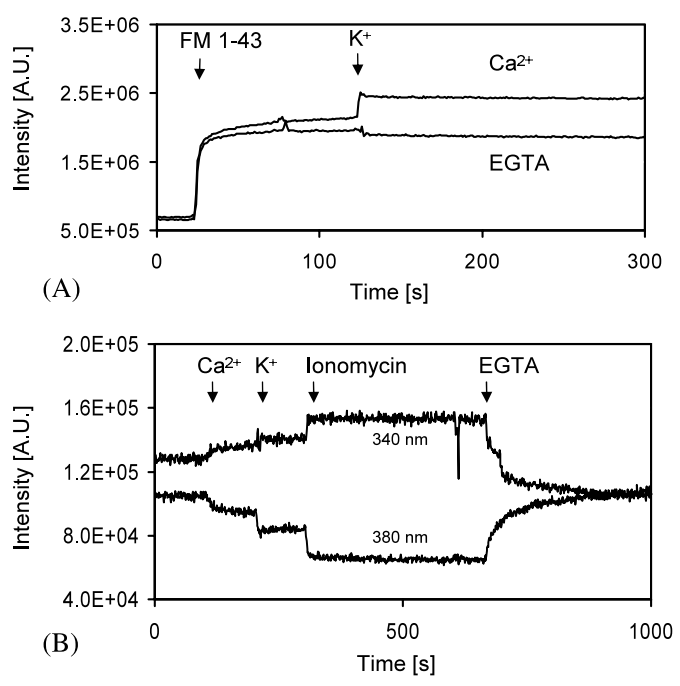

Fig. 6. Exocytosis and synaptosomal free $\mathrm{Ca}^{2+}$ in mouse synaptosomes. (A) Measurement of exocytosis of wild-type synaptosomes with FM 1-43 as described in the text. The upper curve represents the depolarization with $\mathrm{KCl}(50 \mathrm{mM}$ at $125 \mathrm{~s})$, the lower curve is the crosscheck, which was achieved by omitting the addition of $\mathrm{Ca}^{2+}$ before depolarization. Other experiments were carried out with botulinus toxin, which blocks the depolarization. (B) Measurement of $\left[\mathrm{Ca}^{2+}\right]_{\mathrm{i}}$ of synaptosomes with $4 \mu \mathrm{M}$ fura-2-AM. At $100 \mathrm{~s}$ addition of $\mathrm{CaCl}_{2}(1.3 \mathrm{mM})$, at $200 \mathrm{~s}$ addition of $\mathrm{KCl}(50 \mathrm{mM})$, at $300 \mathrm{~s}$ addition of ionomycin $(25 \mu \mathrm{M})$, at $650 \mathrm{~s}$ EGTA $(10 \mathrm{mM})$.

Synaptic degeneration is an early and prominent feature in these diseases, and it has been hypothesized that it may in part be due to alterations in the distribution of free copper ions. However, only limited data exist on the release of copper at the synaptic cleft (Hartter and Barnea, 1988; Kardos et al., 1990), a phenomenon that could be involved in the pathogenic mechanisms of synaptic degeneration in these diseases. To study the release of copper at the synaptic cleft in vivo, we tried to identify a fluorophore that is selectively quenched by copper ions. TSPP was observed to be quenched selectively and rapidly (Fig. 5E) at $645 \mathrm{~nm}$ by $\mathrm{Cu}^{2+}$ and additionally by $\mathrm{Zn}^{2+}$ at $605 \mathrm{~nm}$. As each of the ions did not influence the spectrum of the other, TSPP even allows the measurement of concentrations of both ions simultaneously (Fig. 2B). The fluorescence at $645 \mathrm{~nm}$ was not significantly affected by any of the metal ions tested, except $\mathrm{Fe}^{3+}$. The affinity of $\mathrm{Fe}^{3+}$ to TSPP, however, was found to be more than 20 times smaller than that of $\mathrm{Cu}^{2+}$. The influence of $\mathrm{Cu}^{+}$was not tested in vitro and thus a differentiation cannot be made with the dye in vivo. In addition, the ionic radius of $\mathrm{Cu}^{+}$is not favorable for complexation with TSPP. Actually, a number of intracellular copper-chaperones (e.g. Ccs, Cox17) have been found, that bind copper in its monovalent state (Puig and Thiele, 2002). Considering the reducing environment of the cytosol, it is generally accepted that inside the neurons there is a considerable amount of $\mathrm{Cu}^{+}$. However following extracellular release the labile $\mathrm{Cu}^{+}$ions get in contact with oxygen and are 
readily oxidized to $\mathrm{Cu}^{2+}$ (Frausto da Silva et al., 2001). In our experiments we measure only directly released $\mathrm{Cu}^{2+}$ ions respectively released and subsequent oxidized $\mathrm{Cu}^{+}$ions. The properties of TSPP did not change significantly within the range of $\mathrm{pH}$ or temperature used normally for biological samples (around $\mathrm{pH} 7.0$ and $35{ }^{\circ} \mathrm{C}$ ). Furthermore, TSPP seems to be innocuous to living matter, which is confirmed by Streleckova et al. (1995). In the short period examined, the dye did not harm either the mouse synaptosomes or the bovine chromaffine cells and also did not penetrate the cell membrane. One drawback of TSPP is the high absorbance, which causes only very low fluorescence intensities as a consequence of an inner filtering effect. This could be overcome via a two-photon excitation process.

Since TSPP can be used to measure $\mathrm{Cu}$ concentrations in solutions, we demonstrate here for the first time that TSPP can also be used to observe copper release from active synaptosomes. Three lines of evidence indicate that the variations of the TSPP fluorescence we observed are actually caused by synaptic vesicle release: (i) the protocol used to depolarize synaptosomes in the presence of TSPP indeed led to a depolarization as measured with FURA and also to a neurotransmitter vesicle release as tested by measuring the release of glutamate. (ii) The observed change in fluorescence of TSPP after addition of $\mathrm{KCl}(50 \mathrm{mM})$ disappeared when the buffer did not contain $\mathrm{Ca}^{2+}$. The omission of $\mathrm{Ca}^{2+}$ in the buffer is known to block vesicle release from synaptosomes induced by high $\mathrm{KCl}$ depolarization. (iii) The release of copper as observed with TSPP following depolarization of the synaptosomes was not observed after the addition of botulinus toxin, known to block the release of synaptic vesicles, selectively.

The results of the second, independent method utilizing ICP-MS, confirmed the depolarization-induced release of copper, and support that the observed fluorescence quenching was indeed caused by vesicle release of copper.

We consider it unlikely that the TSPP signal measured at $645 \mathrm{~nm}$ was substantially confounded by iron cations since the maximum content of $\mathrm{Fe}^{2+}$ and $\mathrm{Fe}^{3+}$ together in synaptic vesicles was found to be only twice as much as the content of $\mathrm{Cu}$, determined by ICP-MS. Similar ratios were measured using atomic absorption spectroscopy in rat synaptic vesicles preparations (Rajan et al., 1976). As stated above, this is not enough to have a significant influence on the fluorescence signal of TSPP, since the dissociation constant $K_{\mathrm{d}}$ in vitro for $\mathrm{Cu}^{2+}$ is 20 times lower that for $\mathrm{Fe}^{3+}$.

Using the presented methods for studying synaptosomes, we found $3.9 \pm 1.0 \mathrm{ng}$ copper/mg protein to be released, determined by ICP-MS. This is around $10 \%$ of the total copper found in synaptosomal preparations using the same protocol $(39 \pm 9 \mathrm{ng} \mathrm{Cu} / \mathrm{mg}$ protein; Herms et al., 1999), This value is reasonable, taking into account that there are many proteins within the synaptosomes, that are not being released, especially within mitochondria, and which need copper. Our findings also support studies with radioactively labeled copper in hypothalamic slices which show that previously loaded copper is released with synaptic vesicle fusion (Hartter and Barnea, 1988).

Because copper ions are mainly bound to transport proteins, the concentrations measured with TSPP are probably lower than the actual ones. The concentration of the TSPP and the dissociation constants of copper binding proteins determined the actual amount of copper detected. Note, that some transport proteins such as caeruloplasmin (Wirth and Linder, 1985; Loeffler et al., 1996) relevant to the copper metabolism have higher or similar dissociation constants as TSPP (caeruloplasmin $0.1 \mu \mathrm{M}$ in Orena et al. (1986); Menke's protein $46 \mu \mathrm{M}$ in Jensen et al. (1999)). To estimate the influence of the binding constant of the protein and the TSPP concentration we use Eq. (14) and find

$\left(\frac{1}{f_{\text {Protein }}}-1\right) \cdot \frac{K_{\mathrm{TSPP}}}{K_{\text {Protein }}}=\left(\frac{1}{f_{\mathrm{TSPP}}}-1\right)$,

with $\quad f_{\text {Protein }}=[$ Protein $-\mathrm{Cu}] /[\text { Protein }]_{t}=k \cdot[\mathrm{TSPP}-$ $\mathrm{Cu}] / l \cdot[\mathrm{TSPP}]_{t}=(k / l) \cdot f_{\mathrm{TSPP}}, k=[$ Protein $-\mathrm{Cu}] /[\mathrm{TSPP}-$ $\mathrm{Cu}$ ] representing the part of copper, which is not detected by TSPP, while $l$ gives the ratio of the concentrations of protein and dye. Substituting $K_{\mathrm{TSPP}} /$ $K_{\text {Protein }}$ with $K$, we find:

$$
\begin{aligned}
& \left(\frac{l}{k} \cdot \frac{1}{f_{\mathrm{TSPP}}}-1\right) \cdot K=\left(\frac{1}{f_{\mathrm{TSPP}}}-1\right) \\
& \Leftrightarrow k=l \cdot[\underbrace{\frac{K}{f_{\mathrm{TSPP}} \cdot(K-1)+1}}_{\#}] .
\end{aligned}
$$

As the volume of the synapses is negligible compared to that of the cuvette, $l$ is very small and with similar dissociation constants (thus $K \approx 1$ ) and therefore $l \approx k$. However, this general reasoning valid for all kinds of fluorescence probes follows thermodynamic stability constants while under experimental conditions kinetic control is expected. In conclusion, TSPP like any other fluorescent probe can only detect a certain fraction of the total copper ions, in contrast to ICP-MS which measures the total copper content.

With the above results, it is possible to estimate the concentration of copper in the synaptic vesicles and in the synapse. We found with TSPP a release of $0.9 \pm 0.1$ $\mathrm{ng} \mathrm{Cu} / \mathrm{mg}$ protein. This results in copper concentration of

$[\mathrm{Cu}]=1.4 \pm 0.2 \times 10^{-5}\left[\frac{\mathrm{mmol} \mathrm{Cu}}{\mathrm{g} \text { Protein }}\right] \cdot$ p.c. 
This is a bit higher than the fit from Fig. $5 \mathrm{~F}(1.0 \pm$ $0.3 \times 10^{-5} \mathrm{mmol} \mathrm{Cu} / \mathrm{g}$ protein), but more exact. This is due to the fact, that for calculating the mean, we used always the same protein content and measured about four times more values. Using Eq. (11) this yields

$[\mathrm{Cu}]_{\text {vesicle }}=\frac{1.4 \pm 0.2 \times 10^{-5}(\mathrm{mmol} \mathrm{Cu} / \mathrm{g} \text { Protein }) \cdot \rho_{\text {synaptosome }}}{\left(1-f_{\mathrm{FM}}\right) \cdot d_{\text {synaptosomes }}^{2} \cdot d_{\text {vesicle }} \cdot(1 / 6) \cdot \pi}$.

As mentioned before, we take an average value of 0.6 $\mu \mathrm{m}$ for $d_{\text {synaptosomes }}$ and $0.06 \mu \mathrm{m}$ for $d_{\text {vesicle }}$ (Dunkley et al., 1986, 1988). Theoretically, the increase in membrane area $1-f_{\mathrm{FM}}$ can be calculated by the ratio of the membrane areas $A_{\text {synaptosome }}$ of one synaptosome and $A_{\text {vesicle }}$ of one vesicle. Eq. (8) yields:

$1-f_{\mathrm{FM}}=\frac{A_{\text {vesicle }}}{A_{\text {synaptosome }}}=\frac{n_{\text {vesicles }} \cdot 4 \pi d_{\text {vesicle }}^{2}}{4 \pi d_{\text {synaptosome }}^{2}}$

$=n_{\text {vesicles }}\left(\frac{d_{\text {vesicle }}}{d_{\text {synaptosome }}}\right)^{2}$,

$=0.01 \cdot n_{\text {vesicles }}$,

where $n_{\text {vesicles }}$ is the average number of vesicles per synaptosome. With FM 1-43 we measured a mean increase in membrane area of $1-f_{\mathrm{FM}}=0.05$, so $n_{\text {vesicles }}=5$. In the literature (Hajós, 1980; Dunkley et al., 1986,1988$), n_{\text {vesicles }}$ is found to be $5-6 . \rho_{\text {synaptosome }}$ can be estimated from the volume of the pellets, which was found to be approximately $100 \mu \mathrm{l}$ : the volume of a single synaptosome is then approximated via

$V_{\text {synaptosome }}=\frac{4}{3} \cdot \pi\left(\frac{d_{\text {synaptosome }}}{2}\right)^{2}=1.1 \times 10^{-10} \mu 1$.

Therefore, in the pellet there were about $n_{\text {synaptosome }}=$ $100 \mu \mathrm{l} / 1.1 \times 10^{-10} \mu \mathrm{l}=9.1 \times 10^{11}$ synaptosomes with a protein content of $2.5 \mathrm{mg}$. So $\rho_{\text {synaptosome }}=2.5 \mathrm{mg} /$ $9.1 \times 10^{11}$ synaptosomes $=2.7 \times 10^{-15} \mathrm{~g}$ per synaptosome.

As there may also be impurities, for instance membranes of destroyed synaptosomes, the actual number for $n_{\text {synaptosome }}$ can be smaller. However, electronmicroscopic images indicated that the preparation results in a very pure fraction of synaptosomes. Furthermore, centrifugation compresses the space between the synaptosomes to a minimum, while their volume itself is unchanged as long as they are not destroyed, as the intracellular fluid are incompressible. All the values have estimated standard errors of 5maximal $10 \%$, the biggest source of error being $\rho_{\text {synaptosome. }}$ Substituting the predicted values of $d_{\text {vesicle }}$, $d_{\text {synaptosome }}, \rho_{\text {synaptosome }}$ and $1-f_{\mathrm{FM}}$ in Eq. (19), the concentration of copper in synaptic vesicles is determined to be $67 \pm 7 \mu \mathrm{M} \mathrm{Cu}$ (that is about 5 ions per vesicle), because of the error in $n_{\text {synaptosome }}$ is likely to be larger. With the fit from Fig. $5 \mathrm{~F}$ we get $48 \pm 15 \mu \mathrm{M}$.
Depending on the number of released vesicles $n_{\text {vesicle }}$ per synaptosome, we get a concentration in the synaptic cleft of

$$
\begin{aligned}
{[\mathrm{Cu}]_{\text {synapse }} } & =\frac{[\mathrm{Cu}]_{\text {vesicle }} \cdot V_{\text {vesicle }}}{V_{\text {synapse }}} \\
& =\frac{[\mathrm{Cu}]_{\text {vesicle }} n_{\text {vesicle }}(1 / 6) \pi d_{\text {vesicle }}^{3}}{V_{\text {synapse }}} .
\end{aligned}
$$

The synaptic cleft measures about $18 \mathrm{~nm}$ in distance and $(0.8 \mu \mathrm{m})^{2}$ in area (Hajos, 1980). So the volume of a synapse $V_{\text {synapse }}$ equals $0.012 \mu \mathrm{m}^{3}$ (while the volume of a synaptic vesicle $V_{\text {vesicle }}$ with the assumed diameter of $0.06 \mu \mathrm{m}$ is about 100 times smaller). The number of released vesicles is about $n_{\text {vesicle }}=5$, as stated above. Thus, the concentration in the synaptic cleft after depolarization is around $[\mathrm{Cu}]_{\text {synapse }} \approx 3.2 \pm 0.4 \mu \mathrm{M}$ (or 23 ions). Using the fit value of Fig. $5 \mathrm{~F}$ again, it is $2.3 \pm$ $0.8 \mu \mathrm{M}$.

With ICP-MS we get higher concentrations, because this method also measures the release of copper ions that are bound to proteins with lower $K_{\mathrm{d}}$ than TSPP. Assuming the same dimensions for the synaptosomes, we then calculate from our resulting copper release of $3.9 \pm 1.0 \mathrm{ng} \mathrm{Cu} / \mathrm{mg}$ protein, dividing again by the atomic weight of copper:

$[\mathrm{Cu}]=6.1 \pm 1.5 \times 10^{-5}\left[\frac{\mathrm{mmol} \mathrm{Cu}}{\mathrm{g} \text { Protein }}\right] \cdot$ p.c.

Eqs. (11) and (22) then give a concentration of $[\mathrm{Cu}]_{\text {vesicle }} \approx 291 \pm 75 \mu \mathrm{M}$ and $[\mathrm{Cu}]_{\text {synapse }} \approx 14 \pm 4 \mu \mathrm{M}$.

Kardos et al. (1990) estimated the copper concentration of the synaptic cleft after depolarization to be about $100-250 \mu \mathrm{M}$. This is already above the toxic levels found by Brown et al. (1998), who found 50\% cell death after incubation with $100 \mu \mathrm{M}$ copper. In contrast to this, the concentration of copper in the synaptic cleft determined here is 1-2 orders of magnitude lower. This may be caused by the fact that Kardos' estimation was based on experiments loading synaptosomes with radioactive copper and afterwards determining how much of the loaded copper was released. In contrast to this, we measured the copper physiologically released by the cells, which appears to be a lot smaller.

Using the value of Herms et al. (1999) of $39 \pm 9 \mathrm{ng} \mathrm{Cu} /$ $\mathrm{mg}$ protein in the overall synaptosomal fraction, that is $61 \pm 14 \mathrm{mmol} \mathrm{Cu} / \mathrm{g}$ protein, and multiplying with $\rho_{\text {synaptosome, }}$ one gets an amount of $1.7 \pm 0.4 \times 10^{-15}$ $\mu$ mol $\mathrm{Cu}$ in a single synaptosome. Thus, dividing by $V_{\text {synaptosome }}$ (Eq. (21)), the mean $\mathrm{Cu}$ concentration in the synaptosome is about $15.4 \pm 3.6 \mu \mathrm{M}$. This is smaller than the concentration in the vesicles, so it seems that there is some kind of a transporter which transports $\mathrm{Cu}$ into the vesicles before depolarization. 
In a similar way, we estimated the concentration of $\mathrm{Zn}$ in the synaptic vesicles and the synaptic cleft. In this case, most of $\mathrm{Zn}$ seems to be detected by TSPP, as the values $(20.1 \pm 5.5 \mathrm{ng} \mathrm{Cu} / \mathrm{mg}$ protein with TSPP and $15.7 \pm 5.8 \mathrm{ng} \mathrm{Cu} / \mathrm{mg}$ protein with ICP-MS) differ only within the range of their standard error. This can be explained by the fact that the common Zn-binding proteins (Frederickson et al., 2000) have dissociation constants of only $10^{-7}-10^{-3} \mathrm{M}$, e.g. S100b with a $K_{\mathrm{d}}$ of $10^{-7}-10^{-6} \mathrm{M}$, Calmodulin with a $K_{\mathrm{d}}$ of $8 \times 10^{-5}-3 \times$ $10^{-4} \mathrm{M}$ (Baudier et al., 1983) and other major $\mathrm{Zn}$ binding proteins with disscociation constants $K_{\mathrm{d}}$ even in the mM-range (Kumar and Prasad, 2000). Using the values above, we find:

$$
\begin{gathered}
{[\mathrm{Zn}]=31 \pm 8 \times 10^{-5}\left[\frac{\mathrm{mmol} \mathrm{Zn}}{\mathrm{g} \text { Protein }}\right] \cdot \text { p.c. and }} \\
{[\mathrm{Zn}]=24 \pm 9 \times 10^{-5}\left[\frac{\mathrm{mmol} \mathrm{Zn}}{\mathrm{g} \text { Protein }}\right] \cdot \text { p.c. }}
\end{gathered}
$$

with TSPP and ICP-MS, respectively. With Eqs. (11) and (22), this results in a vesicular concentration of $[\mathrm{Zn}]_{\text {vesicle }}=1466 \pm 401$ and $[\mathrm{Zn}]_{\text {vesicle }}=1146 \pm 425 \mu \mathrm{M}$, while the concentrations in the synaptic cleft are $69 \pm 19$ and $54 \pm 20 \mu \mathrm{M}$, respectively. These findings are well in agreement with the literature (concentration of $\mathrm{Zn}$ in the synaptic vesicle $\sim 1-1.4 \mathrm{mM}$ by Frederickson et al. (2000)).

The methods presented here are far simpler than the experiments using radioactive copper (Hartter and Barnea, 1988), for instance they do not require Cu67 and do not depend on an uptake-mechanism. Thus, the methods described here detect the physiologically released copper ions, while in the works of Hartter and Barnea (1988) released copper ions were only measured after filling the synaptosomes with copper. The use of ICP-MS requires about twice as much synaptosomes as the use of TSPP, but it has the advantage of a multielement analysis, independent of their binding to proteins. Results given by TSPP are influenced by the dissociation of the corresponding proteins and oxidation to $\mathrm{Cu}^{2+}$ as mentioned before, but are easier to acquire. TSPP can even be used in a fluorescence microscope for direct visualization of copper metabolism in vivo.

\section{Acknowledgements}

This work was supported by the Deutsche Forschungsgemeinschaft, BMBF, and the Bayerische Forschungsverbund. We thank Peter Schürmann for excellent technical assistance and Dr Neville Vassallo for critical reading of the manuscript.

\section{References}

Adamson P, Hajimohammadreza I, Brammer MJ, Campbell IC, Meldrum BS. Presynaptic glutamate/quisqualate receptor: effects on synaptosomal free calcium concentrations. J Neurochem 1990;55:1850-4.

Baudier J, Haglid K, Haiech J, Gerard D. Zinc ion binding to human brain calcium binding proteins, calmodulin and $\mathrm{S} 100 \mathrm{~b}$ protein. Biochem Biophys Res Commun 1983;114:1138-46.

Biesaga M, Pyrzynska K, Trojanowicz M. Porphyrins in analytical chemistry. A review. Talanta 2000;51:209-24.

Brown DR, Qin K, Herms J, Madlung A, Manson J, Strome R, Fraser P, Kruck T, A. v. Schulz-Schaeffer WJ, Giese A, Westaway D, Kretzschmar H. The cellular prion protein binds copper in vivo. Nature 1997;390:684-7.

Brown DR, Schmidt B, Kretzschmar HA. Effects of copper on survival of prion protein knockout neurons and glia. $\mathbf{J}$ Neurochem 1998;70:1686-93.

Bruns D, Engers S, Yang C, Ossig R, Jeromin A, Jahn R. Inhibition of transmitter release correlates with proteolytic activity of tetanus toxin and botulinus toxin in individual cultured synapses of Hirudo medicinalis. J Neurosci 1997;17:1898-910.

Bush AI. Metals and neuroscience. Curr Opin Chem Biol 2000;4:18491.

DiDonato M, Sarkar B. Copper transport and its alterations in Menkes and Wilson diseases. Biochem Biophys Acta 1997;1360:316.

Dunkley PR, Jarvie PE, Heath JW, Kidd GJ, Rostas JAP. A rapid method for isolation of synaptosomes on Percoll gradient. Brain Res 1986;372:115-29.

Dunkley PR, Heath JW, Harrison SM, Jarvie PE, Glenfield PJ, Rostas JAP. A rapid Percoll gradient procedure for isolation of synaptosomes directly from an S1-fraction: homogeneity and morphology of subcellular fractions. Brain Res 1988;441:59-71.

Falk JE. Porphyrins and Metalloporphyrins. New York: Elsevier, 1975.

Frausto da Silva JJR, Willimas RJP. The Biological Chemistry of the Elements. Oxford: Oxford University Press, 2001:418-36.

Frederickson CJ, Suh SW, Silva D, Frederickson CJ, Thompson RB. Importance of zinc in the central nervous system: the zinccontaining neuron. J Nutr 2000;130:1471S-3S.

Grynkiewicz G, Poenie M, Tsien RY. A new generation of $\mathrm{Ca} 2+$ indicators with greatly improved fluorescence properties. J Biol Chem 1985;260:3440-50.

Hajós F. The structure of cleft material in spine synapses of rat cerebral and cerebellar cortices. Cell Tissue Res 1980;206:477-86.

Hartter DE, Barnea A. Evidence for release of copper in the brain: depolarisation-induced release of newly taken-up 67copper. Synapse 1988;2:412-5.

Haughland RP. Handboook of fluorescent probes and research chemicals. Leiden: Molecular Probes, 1996.

Herms J, Tings T, Madlung A, Gall S, Schürmann P, Giese A, Siebert $\mathrm{H}$, Windl O, Brose N, Kretzschmar HA. Evidence of presynaptic location and function of the prion protein. $\mathrm{J}$ Neurosci 1999; 15:8866-75.

Hoppe W, Lohmann W, Markl H. Biophysik. Heidelberg: Springer, 1982.

Jensen PY, Bonander N, Horn N, Tumer Z, Farver O. Expression, purification and copper-binding studies of the first metal-binding domain of Menkes protein. Eur J Biochem 1999;264:890-6.

Jimenez HR, Julve M, Faus J. A solution study of the protonation and deprotonation equilibria of 5,10,15,20-tetra( $p$-sulphonatophenyl)porphyrin. Stability constants of its magnesium(II), copper(II) and zinc(II) complexes. J Chem Soc Dalton Trans 1991;8:1945-9.

Kao JP. Methods in Cell Biology. New York: Academic Press, 1994. 
Kardos J, Kovács I, Hajós F, Kálmán M, Simonyi M. Nerve endings from rat brain tissue release copper upon depolarization. A possible role in regulating neuronal excitability. Neurosci Lett 1990;103:139-44.

Kumar R, Prasad R. Functional characterization of purified zinc transporter from renal brush border membrane of rat. Biochim Biophys Acta 2000;1509:429-39.

Lakowicz JR. Principles of Fluorescence Spectroscopy. New York: Kluwer Academic, 1999.

Lattanzio FA. The effects of $\mathrm{pH}$ and temperature on fluorescent calcium indicators as determined with Chelex-100 and EDTA buffer systems. Biochem Biophys Res Commun 1989;171:102-8.

Loeffler DA, Le Witt PA, Juneau PL, Sima AA, Nguyen HU, De Maggio AJ, Brickman CM, Brewer GJ, Dick RD, Troyer MD, Kanaley L. Increased regional brain concentration of coeruloplasmin in neurodegenerative disorders. Brain Res 1996;738:265-74.

McMahon HT, Nicholls DG. Transmitter glutamate release from isolated nerve terminals: evidence for biphasic release and triggering by localized Ca2 +. J Neurochem 1991;56:86-94.

Minta A, Kao JP, Tsien RY. Fluorescent indicators for cytosolic calcium based on rhodamine and fluorescein chromophores. J Biol Chem 1989;264:8171-8.

Orena SJ, Goode CA, Linder MC. Binding and uptake of copper from ceruloplasmin. Biochem Biophys Res Commun 1986;139:822-9.
Puig S, Thiele DJ. Molecular mechanisms of copper uptake and distribution. Curr Opin Chem Biol 2002;6:171-80.

Rajan KS, Colburn RW, Davis JM. Distribution of metal ions in the subcellular fractions of several rat brain areas. Life Sci 1976;18:423-32.

Smith C. A persistent activity-dependent facilitation in chromaffin cells is caused by $\mathrm{Ca}^{2+}$ activation of protein kinase C. J Neurosci 1999; 19:589-98.

Smith CB, Betz WJ. Simultaneous independent measurement of endocytosis and exocytosis. Nature 1996;380:531-4.

Streleckova, Kodetova, Pouckova, Zadinova, Lukas, Rokyta, Jirsa. Meso-tetra-(4-sulfonatophenyl)-porphine of low neurotoxicity. Sb Lek 1995; 96:7-13.

Tanaka M. Kinetics of metalloporphyrin formation with particular reference to the metal ion assisted mechanism. Pure Appl Chem 1983;55:151-8.

Turay J, Hambright P. Activation parameters and a mechanism for metal-prophyrin formation reactions. Inorg Chem 1980;19:562-4.

Waggoner DJ, Bartnikas TB, Gitlin JD. The role of copper in neurodegenerative disease. Neurobiol Dis 1999;6:221-30.

Whatley SA, Powell JF, Politopoulou G, Campbell IC, Brammer MJ, Percy NS. Regulation of intracellular free calcium levels by the cellular prion protein. Neuroreport 1995;6:2333-7.

Wirth PL, Linder MC. Distribution of copper among components of human serum. J Natl Cancer Inst 1985;75:277-87. 